\title{
Comparative Analysis by Mathematical Modeling and Simulation of the Two Thermal Systems Using Solar Radiation as a Source of Energy
}

\author{
Petrică Daniel Toma
}

\begin{abstract}
This paper presents comparative analysis by mathematical modeling and simulation of two thermal systems for hot water production consisting of solar collectors and storage tank with and without inbuilt heat exchanger. Thermal hot water systems use solar radiation as the source of energy, and mathematical models of their simulation are developed in Scilab-Xcos. An example of simulation of these thermal systems is also presented in this paper.
\end{abstract}

Keywords - modeling, simulation, solar collectors, thermal system, Xcos

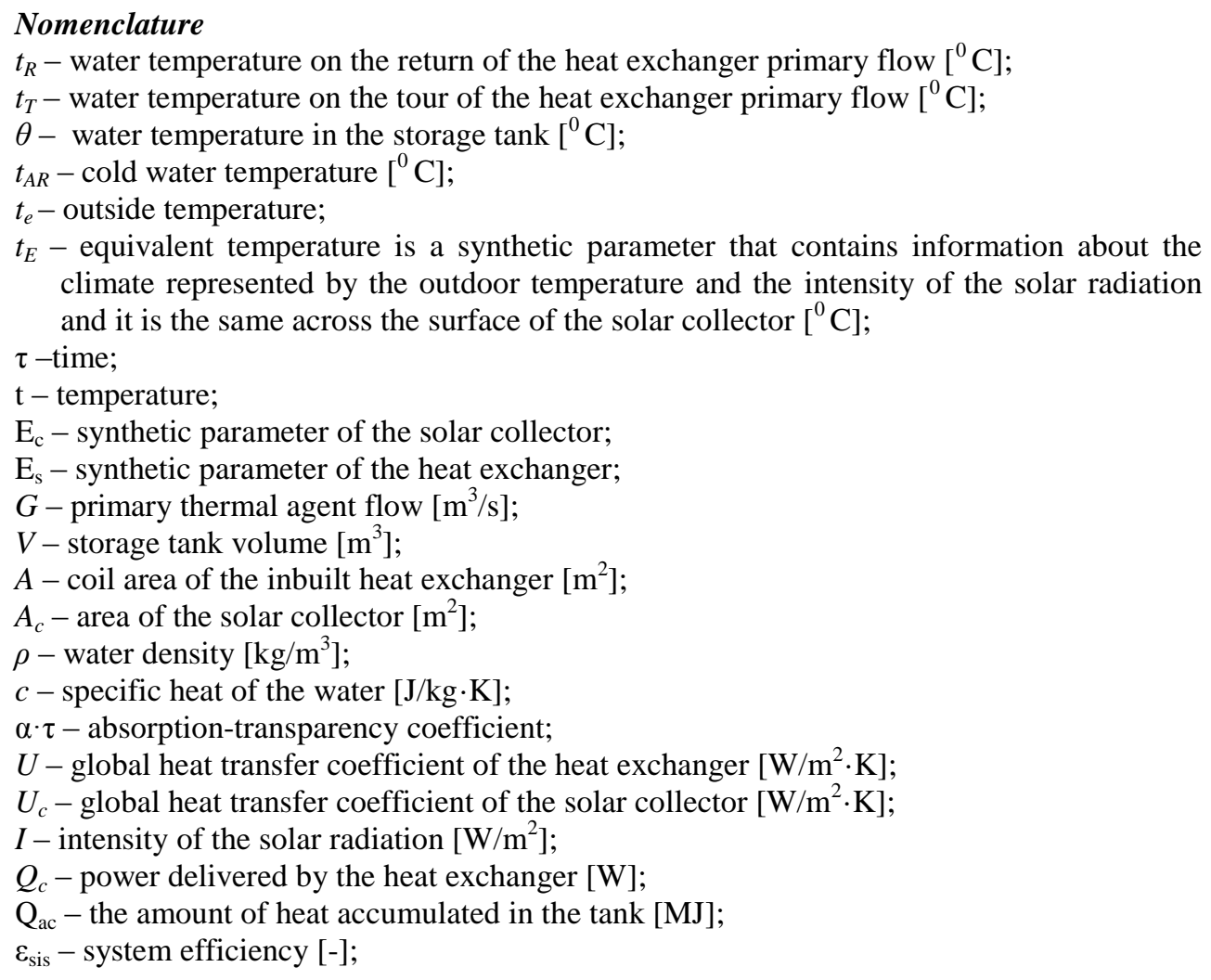


$\eta$ - system performance [-];

$F$ - heat flux correction factor for the solar collector;

$\mathrm{C}_{\text {min }}$ - minimum transfer capacity of the thermal agents (respectively primary thermal agent) $[\mathrm{W} / \mathrm{K}]$;

$\mathrm{NTU}_{\mathrm{s}}$ - the number of the heat exchanger heat transfer units - represents the ratio of the transfer capacity of the heat exchanger surface and the transfer capacity of the primary termic agent.

\section{INTRODUCTION}

Research on thermal systems that use energy as the source of energy, the energy generated by solar radiation has great relevance when conventional sources of energy (those that use hydrocarbons as the source) are limited and pollute the environment [1].

Solar energy is the most impressive and possible source of energy for a certain category of consumers. We make reference here especially to the preparation of domestic hot water.

The solar collector is the corresponding equipment for converting solar energy into thermal energy and transferring it to the fluid that heats up [2, 3].

Within 20 minutes, the sun provides the equivalent of the annual energy consumption of mankind. The capture power of a solar collector, oriented to the south and tilted to 45 degrees is $95 \div 96 \%$ of the solar radiation.

On the territory of Romania, the solar radiation has an annual average between 1000 and $1300 \mathrm{~kW} / \mathrm{m}^{2} /$ year, depending on the geographic area. On a horizontal surface $-1 \mathrm{~m}^{2}$ heat-pipe solar collector, we can capture an annual amount of energy between 900 and 1450 $\mathrm{kWh}$, depending the season of course. Daily average radiation may be 5 times more intense in summer than in the winter. But during winter, during a clear day, we can capture $4 \div 5$ $\mathrm{kWh} / \mathrm{m}^{2} /$ day, the solar radiation captured being independent of the ambient temperature [2].

Using a hot water system that use as a source of energy solar radiation is economically beneficial and does not pollute the environment.

The disadvantage of this system is that solar energy can only be used during the daytime as long as the intensity of the solar radiation is at a rate that allows it to be valorized.

A good thing is that energy can be accumulated when the intensity of solar radiation permits and can be used when the intensity of the solar radiation is at lower levels or zero (during the night). Accumulation of energy can be done in storage tanks.

This type of installations can also be used as heat input to the heating system, reducing the costs of building heat [1].

Solar water heating installations are usually made up of three basic components: solar collectors, the heat exchanger and the storage tank. The role of the heat exchanger is to separate the hot water circuit of the thermal agent circuit recirculated through the collectors, in this way it could be treated against limescale. Heat exchanger systems inbuilt in the storage tank are the most common [2], [4].

Fig. 1 presents a schematic diagram of a thermal system consisting of solar collectors and a hot water storage tank, and in Fig. 2 is a schematic diagram of a thermal system consisting of solar collectors and the hot water storage tank with inbuilt heat exchanger, the themal agent (water) being circulated by pumps.

In this article we will present a comparative analysis of the mathematical model of a thermal system consisting of solar collectors and a hot water storage tank compared to the mathematical model of a thermal system consisting of solar collectors coupled with an inbuilt heat exchanger in a hot water storage tank. 


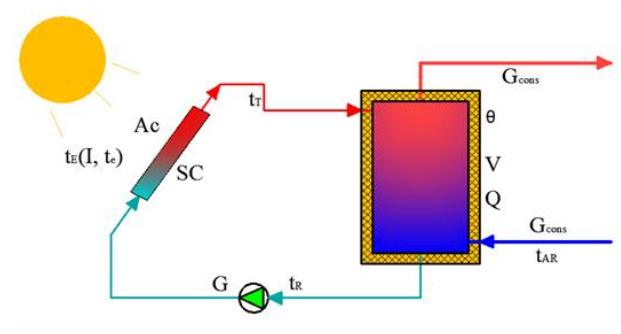

Fig. 1. Scheme of a thermal system consisting of solar collectors and storage tank

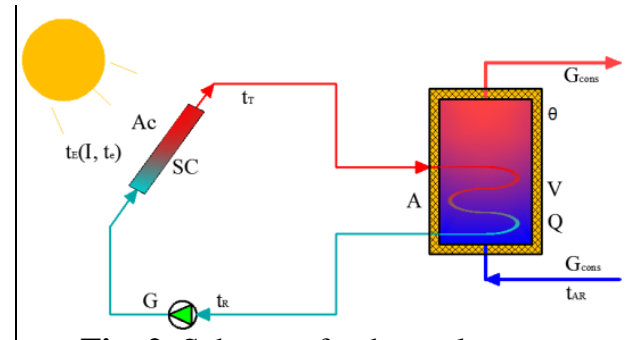

Fig. 2. Scheme of a thermal system consisting of solar collectors and storage tank with an inbuilt heat exchanger [4]

Analyzing comparatively through mathematical modeling and simulation these thermal systems for hot water production that use solar radiations as source are intended to highlight the advantages and disadvantages of each of these systems. This makes it easier for field specialists to design, implement and operate these systems.

\section{MATHEMATICAL MODEL OF A THERMAL SYSTEM CONSISTING OF SOLAR COLLECTORS AND THE HOT WATER STORAGE TANK}

The equations describing the mathematical model are the following $[3,5]$ :

$$
\begin{aligned}
& \frac{d \theta}{d \tau}=\frac{G \cdot\left(t_{T}-\theta\right)}{V}+\frac{G_{\text {cons }} \cdot\left(t_{A R}-\theta\right)}{V} \quad\left[{ }^{0} \mathrm{C}\right] \\
& t_{E}=\frac{\alpha \cdot \tau}{U_{c}} \cdot I+t_{e} \quad\left[{ }^{0} \mathrm{C}\right] \\
& E_{c}=e^{-\left(\frac{F \cdot U_{c} \cdot A_{c}}{G \cdot \rho \cdot c}\right)} \quad[-] \\
& t_{T}=t_{E}+\left(\theta-t_{E}\right) \cdot E_{c} \quad\left[{ }^{0} \mathrm{C}\right] \\
& Q_{c}=G \cdot \rho \cdot c \cdot\left(t_{T}-\theta\right) \quad[\mathrm{W}] \\
& Q_{a c}=\int_{0}^{\tau} G \cdot \rho \cdot c \cdot\left(t_{T}-\theta\right) \cdot d \tau \quad[\mathrm{MJ}] \\
& \varepsilon_{\text {sis }}=\frac{\theta-t_{A R}}{t_{E}-t_{A R}}
\end{aligned}
$$




$$
\eta=\frac{Q_{C}}{A_{C} \cdot I} \quad[-]
$$

It was assumed that the storage tank has no heat loss to the outside environment and does not consume hot water from the tank $[3,5]$.

Starting from the above equations $[3,5]$, we developed the schemes of the figures 3,4 and 5 in Scilab-Xcos [6] with which simulations can be made for various scenarios. Thus, for the various physical characteristics of the inbuilt heat exchanger, storage tank and solar collectors and various solar radiation intensities, external temperatures and heat flow rates, it is possible to see the evolution in time of the water temperatures on the flow and return of the primary heat exchanger, the equivalent temperature, the water temperature in the storage tank the power delivered by the solar installation and the amount of heat accumulated in the storage tank.

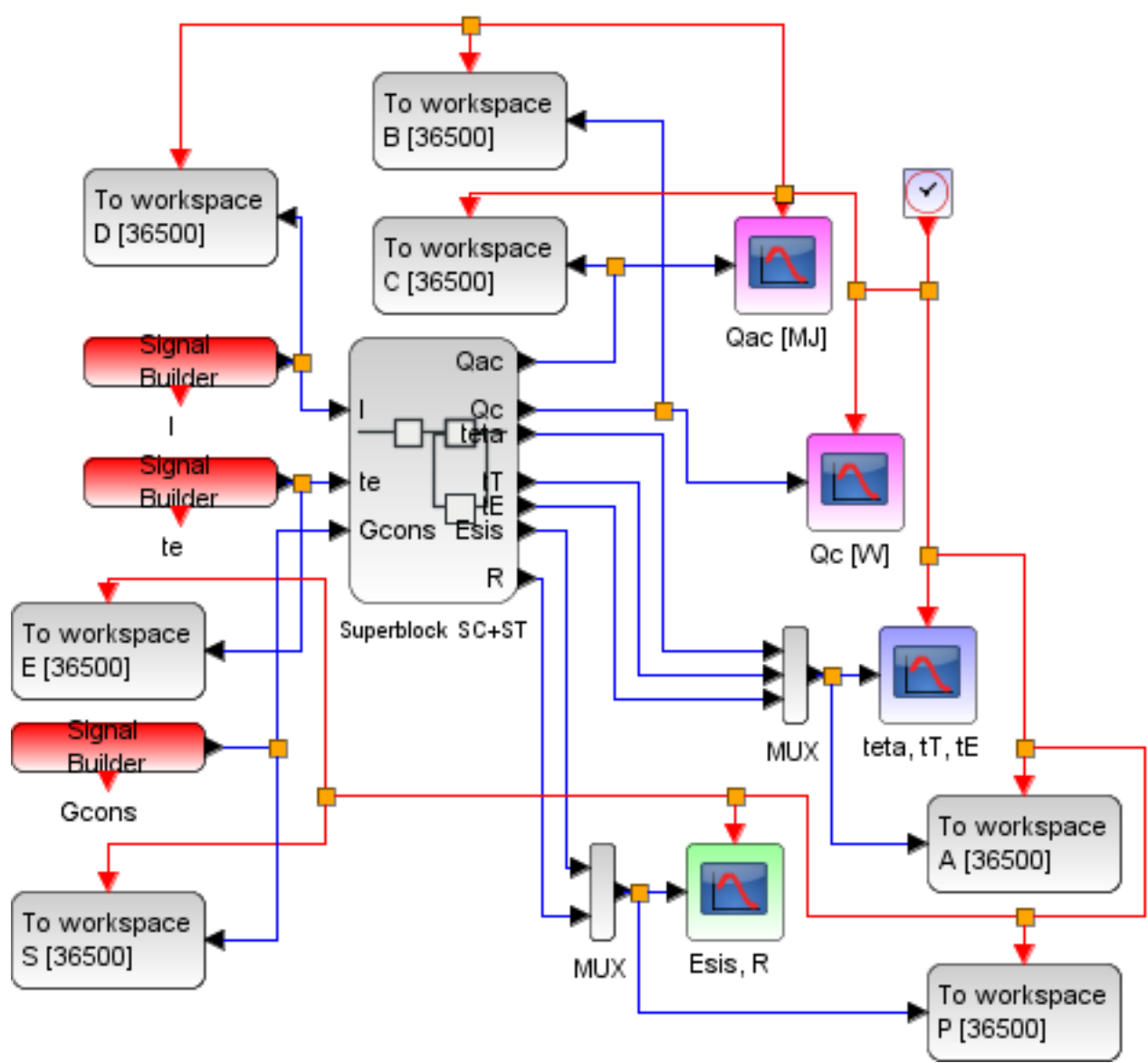

Fig. 3. Scilab-Xcos scheme for simulating a thermal system consisting of solar collectors and storage tank 


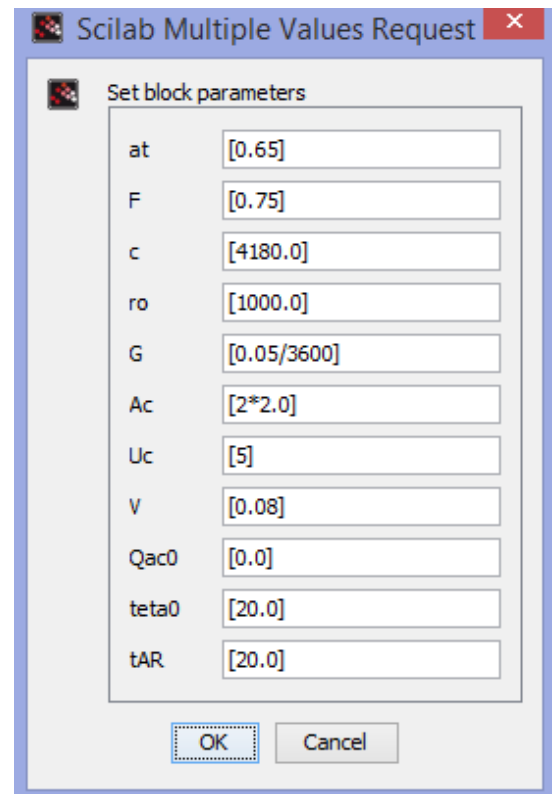

Fig. 4. Superblock SC + ST parameters box in figure 3

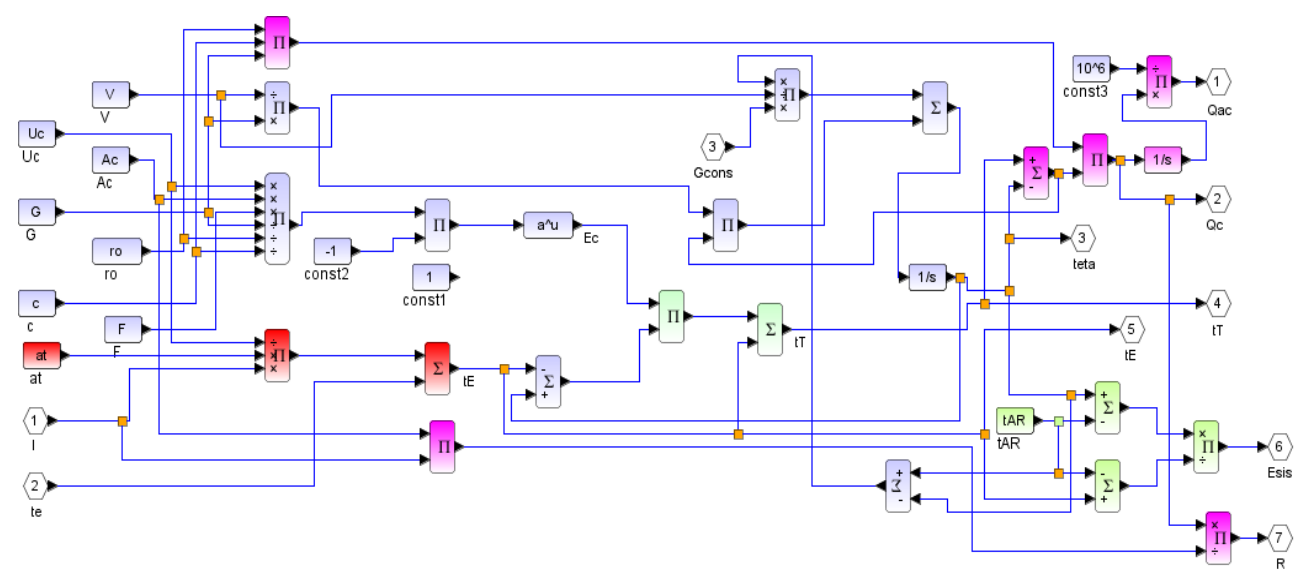

Fig. 5. Scilab-Xcos diagram of the superblock $\mathrm{SC}+\mathrm{ST}$ in Fig. 3 was developed starting from equations $1 \div 8$

\section{MATHEMATICAL MODEL OF A THERMAL SYSTEM CONSISTING OF SOLAR COLLECTORS AND STORAGE TANK WITH AN INBUILT HEAT EXCHENGER [4]}

The equations describing the mathematical model are the following $[3,5]$ :

$$
\frac{d \theta}{d \tau}=-\frac{G \cdot\left(1-E_{s}\right)+G_{c o n s}}{V} \cdot \theta+\frac{G \cdot\left(1-E_{s}\right)}{V} \cdot t_{T}+\frac{G_{c o n s}}{V} \cdot t_{A R} \quad\left[{ }^{0} \mathrm{C}\right](9)
$$




$$
\begin{aligned}
& t_{E}=\frac{\alpha \cdot \tau}{U_{c}} \cdot I+t_{e} \quad\left[{ }^{0} \mathrm{C}\right] \\
& E_{c}=e^{-\left(\frac{F \cdot U_{c} \cdot A_{c}}{G \cdot \rho \cdot c}\right)} \\
& E_{s}=e^{-N T U_{S}} \quad[-] \\
& N T U_{s}=\frac{U \cdot A}{G \cdot \rho \cdot c} \quad[-] \\
& t_{T}=\frac{\left(1-E_{s}\right) \cdot E_{c}}{1-E_{s} \cdot E_{c}} \cdot \theta+\frac{\left(1-E_{c}\right)}{1-E_{s} \cdot E_{c}} \cdot t_{E} \quad\left[{ }^{0} \mathrm{C}\right] \\
& t_{R}=E_{s} \cdot t_{T}+\left(1-E_{s}\right) \cdot \theta \quad\left[{ }^{0} \mathrm{C}\right] \\
& Q_{c}=G \cdot \rho \cdot c \cdot\left(t_{T}-t_{R}\right) \quad[\mathrm{W}] \\
& Q_{a c}=\int_{0}^{\tau} G \cdot \rho \cdot c \cdot\left(t_{T}-t_{R}\right) \cdot d \tau \quad[\mathrm{MJ}] \\
& \varepsilon_{s i s}=\frac{\theta-t_{A R}}{t_{E}-t_{A R}} \quad[-] \\
& \eta=\frac{Q_{C}}{A_{C} \cdot I}
\end{aligned}
$$

It was assumed that the storage tank has no heat loss to the outside environment and does not consume hot water from the tank $[3,5]$.

Starting from the above equations $[3,5]$, we developed the schemes of the figures 2,3 and 4 in Scilab-Xcos [6] with which simulations can be made for various scenarios. Thus, for the various physical characteristics of the inbuilt heat exchanger, storage tank and solar collectors and various solar radiation intensities, external temperatures and heat flow rates, it is possible to see the evolution in time of the water temperatures on the flow and return of the primary heat exchanger, the equivalent temperature, the water temperature in the storage tank and the power delivered by the heat exchanger. 


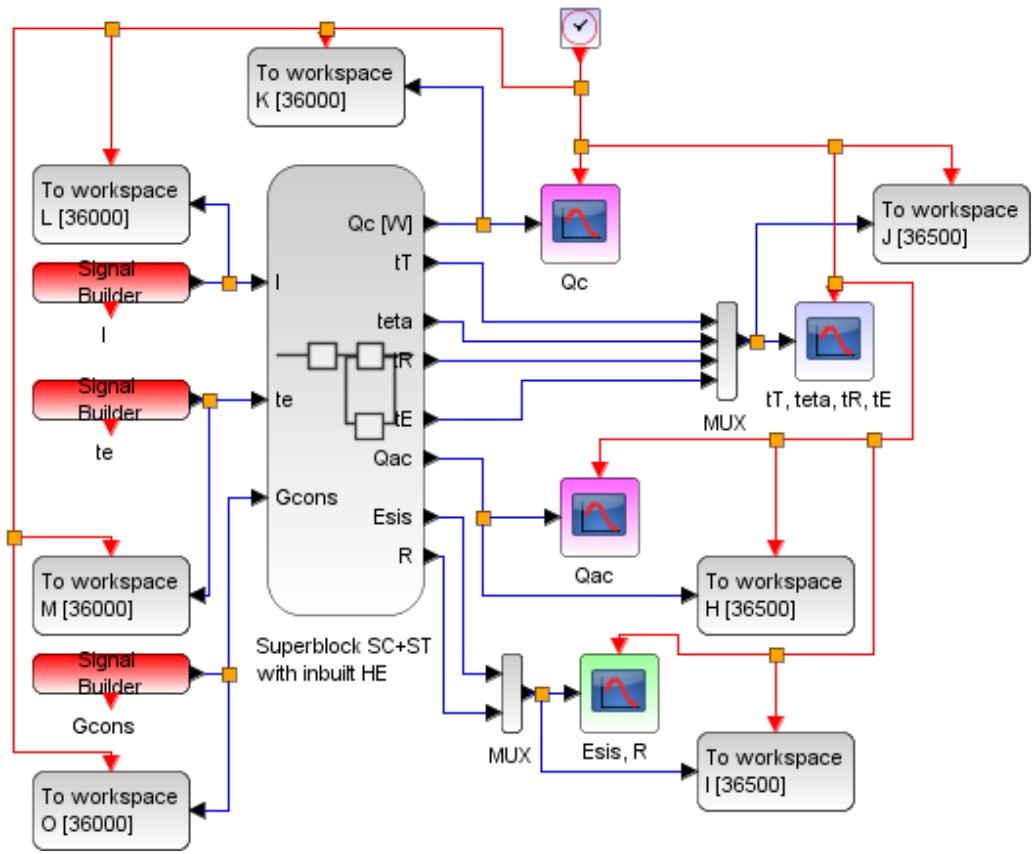

Fig. 6. Scilab-Xcos scheme for simulating a thermal a thermal system consisting of solar collectors and storage tank with an inbuilt heat exchanger [4]

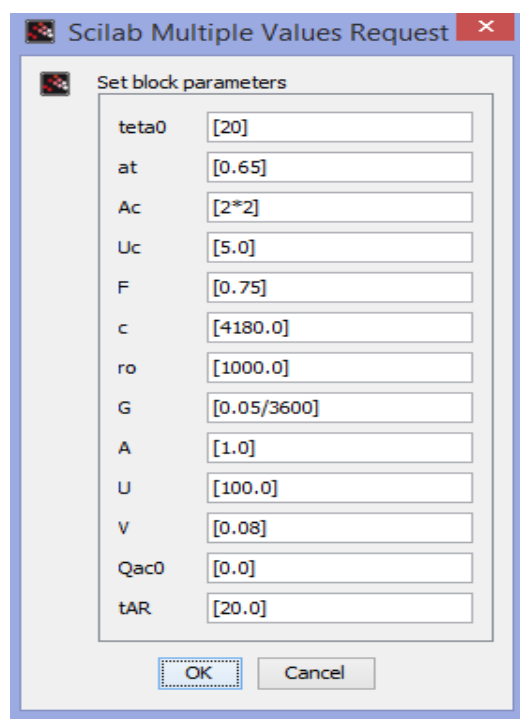

Fig. 7. Superblock SC + ST parameters box with inbuilt HE in Fig. 6 [4]

The Scilab-Xcos environment has a free license. The programs being realized in this environment, allows the immediate implementation without cost in the thermal systems. By simulating it, the thermal systems can be made more efficient. This programs is also useful for specialists who work in the design of thermal systems and those who perform mathematical modeling and simulation programs [4]. 


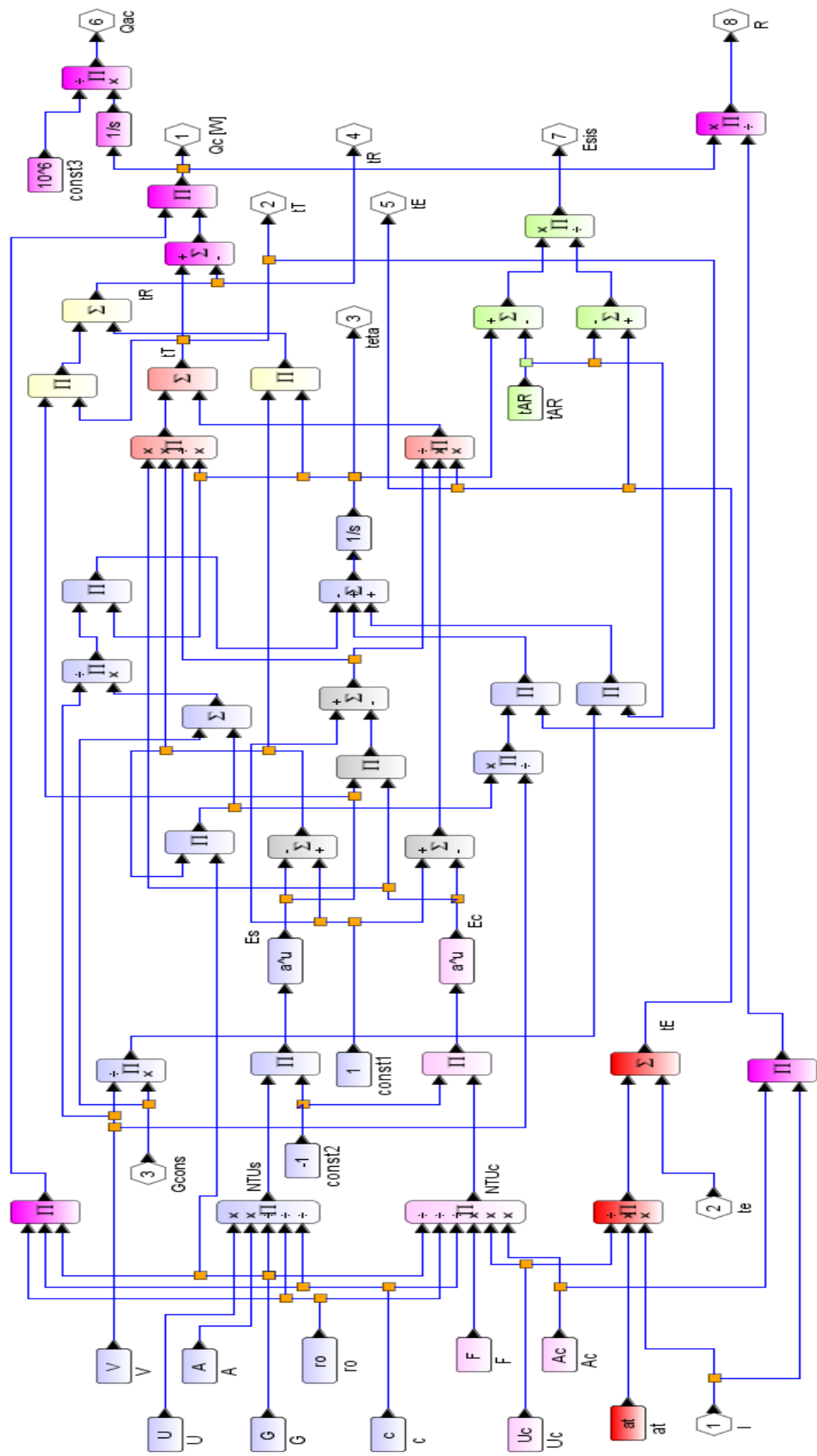

Fig. 8. Scilab-Xcos diagram of the superblock $\mathrm{SC}+\mathrm{ST}$ with inbuilt HE in Fig. 6 was developed starting from equations $9 \div 18$ [4] 


\subsection{Example of simulation}

Initial data [5]:

- $\quad$ Volume of the storage tank $V=0.08 \mathrm{~m}^{3}$;

- Initial water temperature in the storage $\operatorname{tank} \theta_{0}=20^{\circ} \mathrm{C}$;

- $\quad$ Cold water temperature $t_{A R}=20^{\circ} \mathrm{C}$;

- $\quad$ Coil area of the inbuilt heat exchanger $A=1 \mathrm{~m}^{2}$;

- Global heat transfer coefficient of the coil inbuilt heat exchanger $U=100 \mathrm{~W} / \mathrm{m}^{2} \cdot \mathrm{K}$

- Flow rate of the thermic agent delivered through the system $G=0.05 \cdot 3600 \mathrm{~m}^{3} / \mathrm{s}$

- $\quad$ Area of solar collectors $A_{c}=2 \cdot 2 \mathrm{~m}^{2}$;

- Transparency-absorption coefficient of the solar collector $\alpha \cdot \tau=0.65$;

- $\quad$ Geometric correction factor $F=0.75$;

- Global heat transfer coefficient of the solar collector $U_{c}=5 \mathrm{~W} / \mathrm{m}^{2} \cdot K$;

The consumption flow of water $\mathrm{G}_{\text {cons }}\left[\mathrm{m}^{3} / \mathrm{s}\right]$ during the simulated period has the evolution shown in the graph below (Fig. 9).

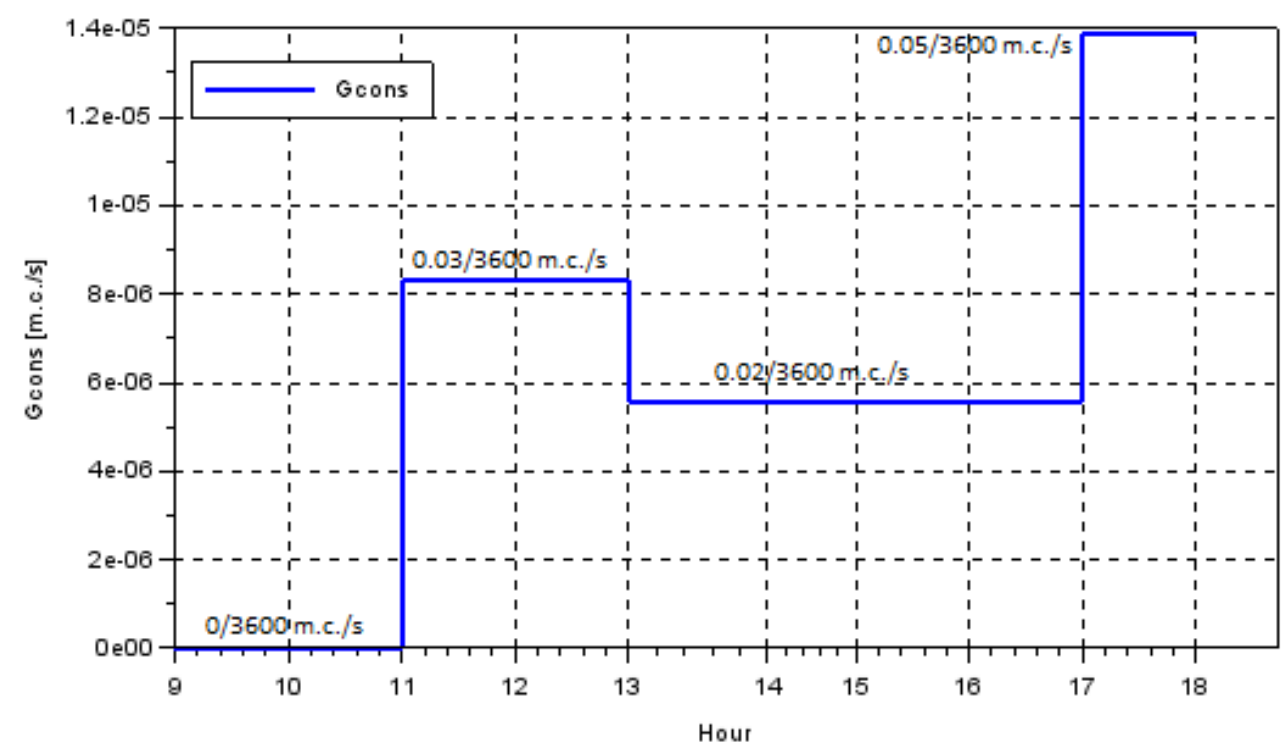

Fig. 9. The evolution in time of the water flow consumed

- $\quad$ Outside air temperature $t_{e}\left[{ }^{0} \mathrm{C}\right]$ during the simulated time period (one day from July from 09 to 18 hours) in Bucharest city has the evolution according to the graph below (Fig. 10) [7]; 
sciendo

104 Ovidius University Annals Series: Civil Engineering, Year 22, 2020

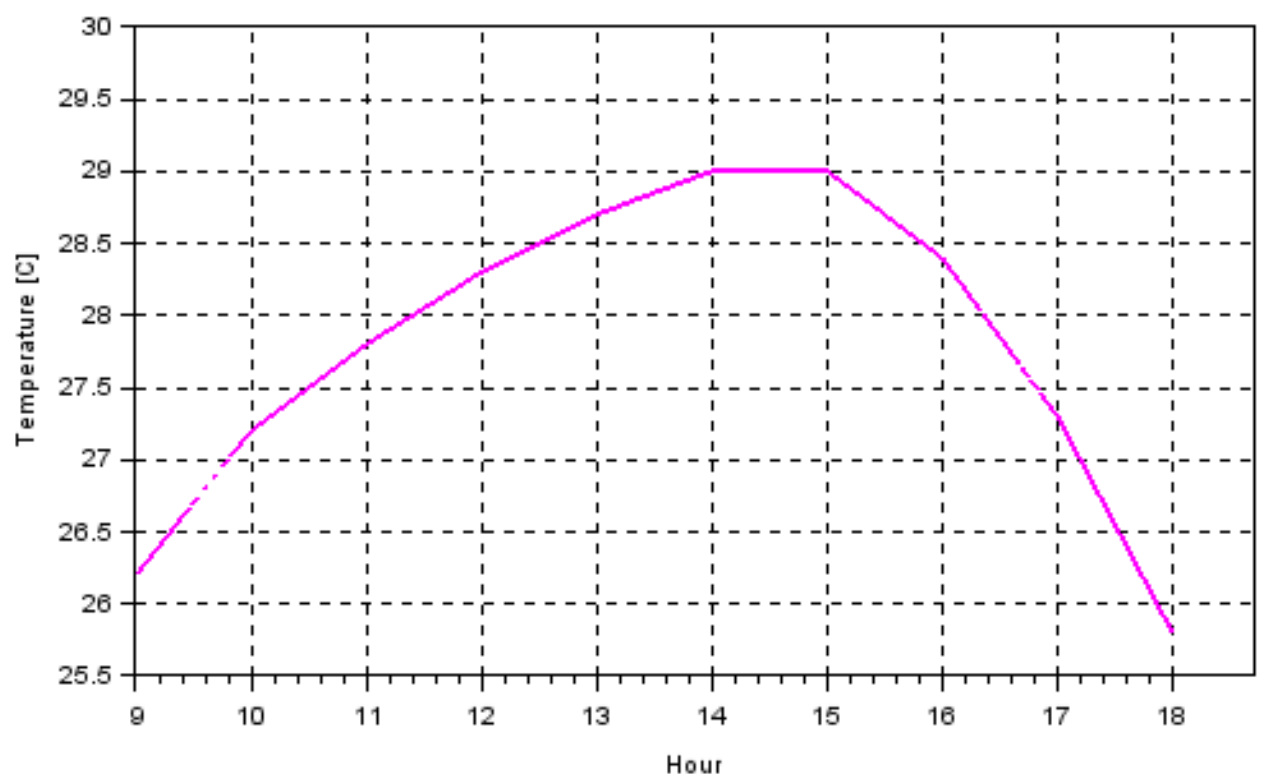

Fig. 10. Evolution of the outside air temperature over simulated time period

- Intensity of the solar radiation $I\left[\mathrm{~W} / \mathrm{m}^{2}\right]$ during the simulated time period (one day from July from 09 to 18 hours) in Bucharest city has the evolution according to the graph below (Fig. 11) [7];

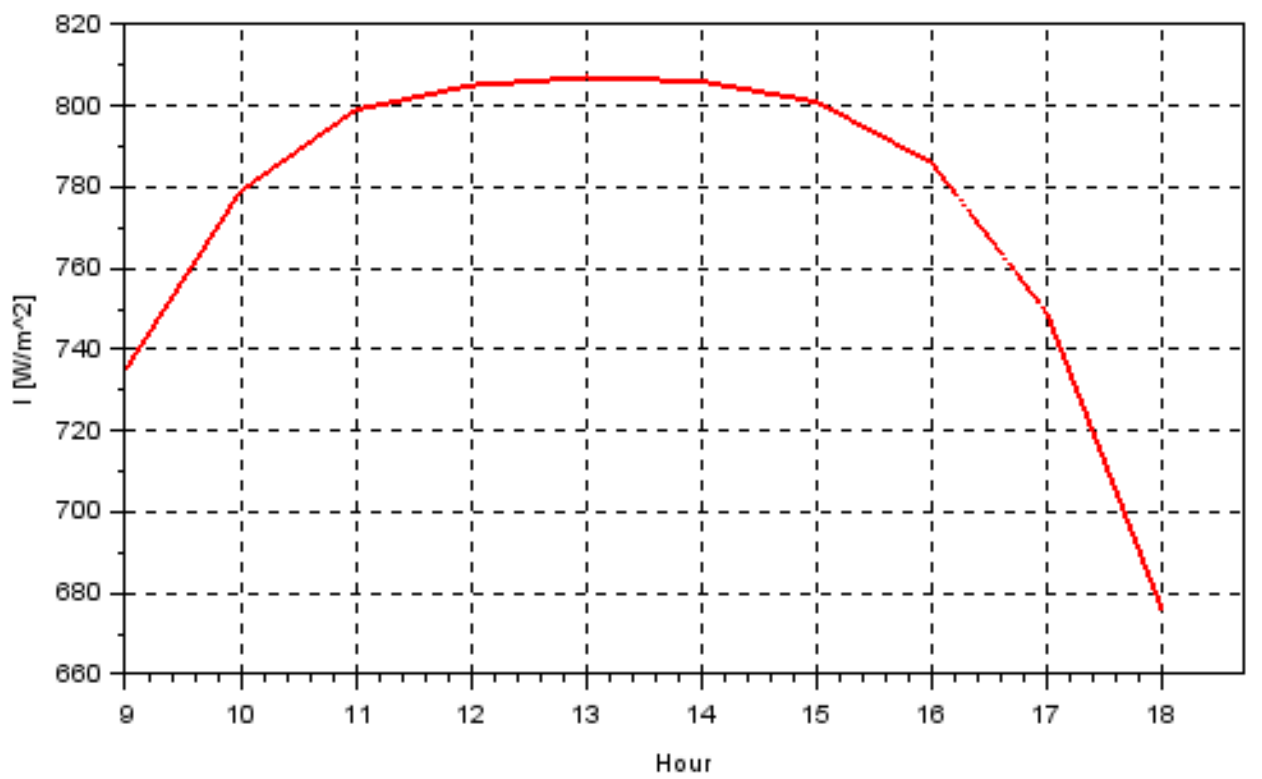

Fig. 11. Evolution of solar radiation intensity over simulated time

Following the simulation, it can be seen graphically for both systems how the water temperatures, the power delivered to the system, the amount of heat accumulated in the 
tank, the system efficiency and performance evolved during the simulated time period and for the simulation conditions (Figs. 12 to 15).

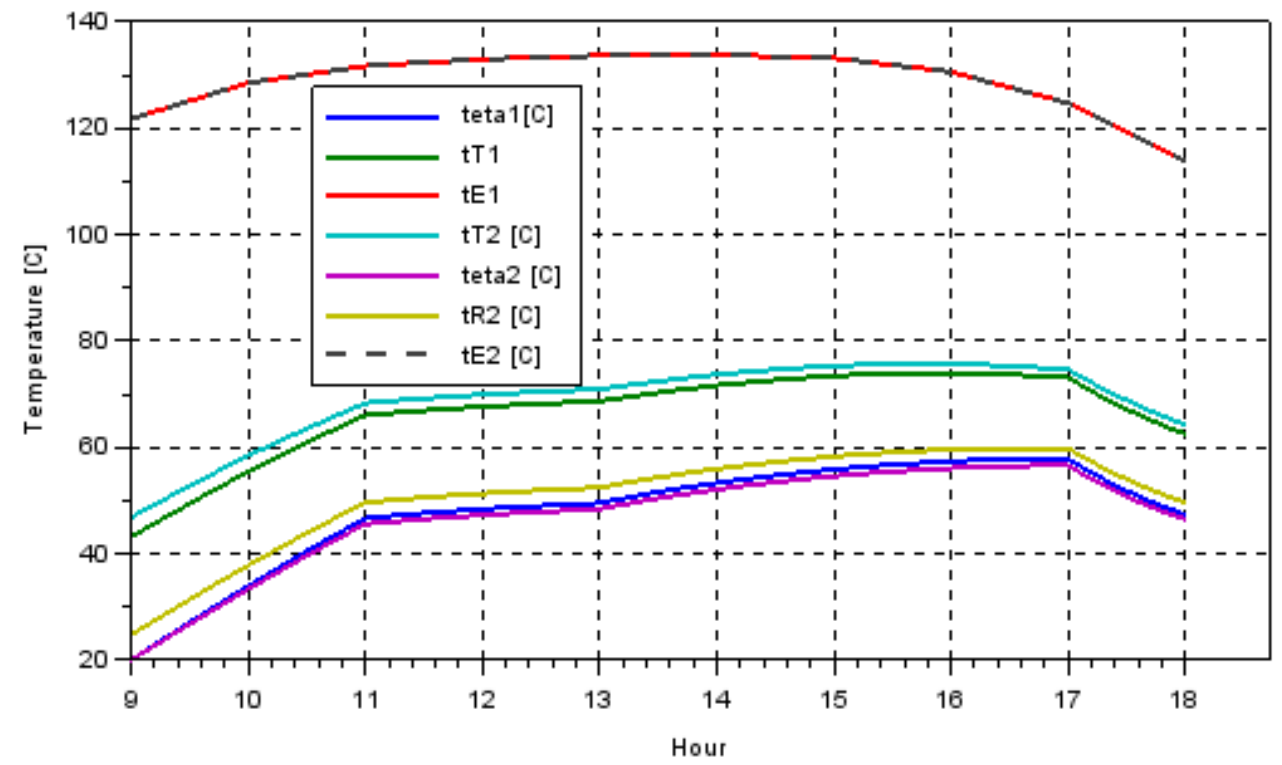

Fig. 12. Time evolution of water temperatures on the flow and return of the primary flow of the heat exchanger, water temperature in the storage tank and the equivalent temperature over simulation time period for both systems

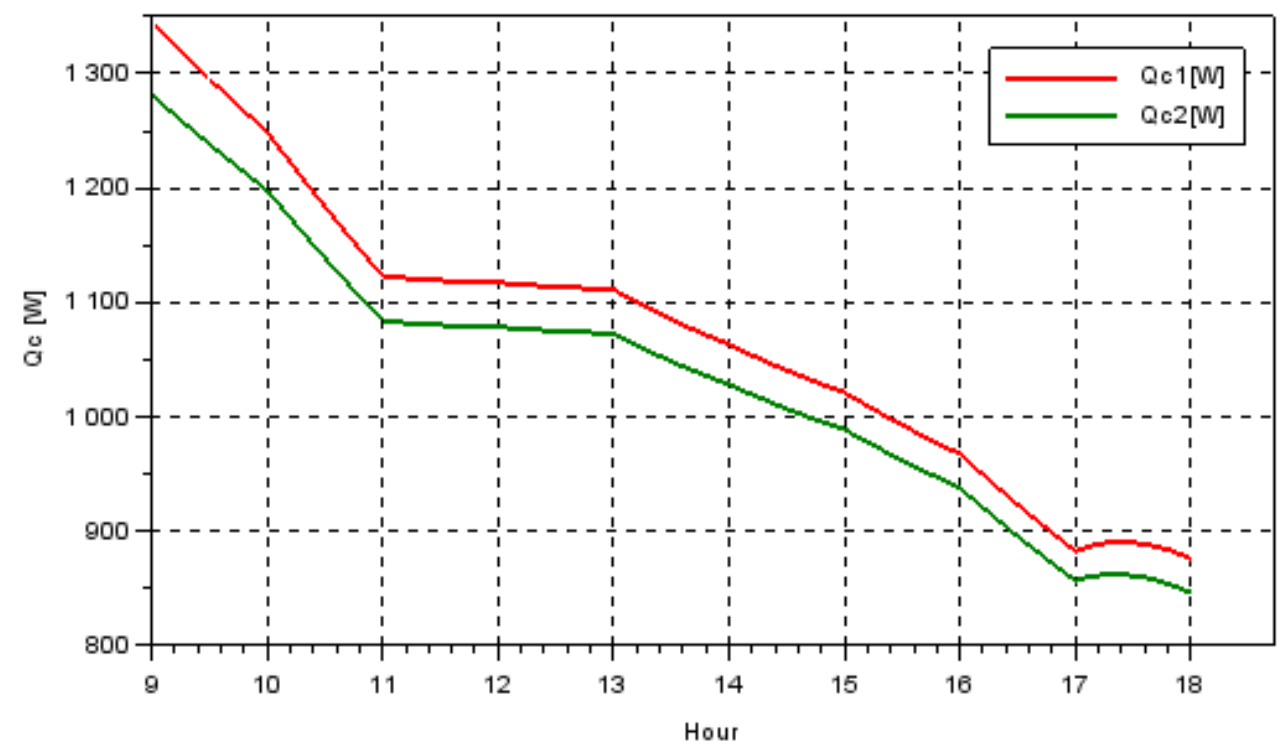

Fig. 13. Time evolution of the power delivered by the solar installation over simulation time period for both systems 


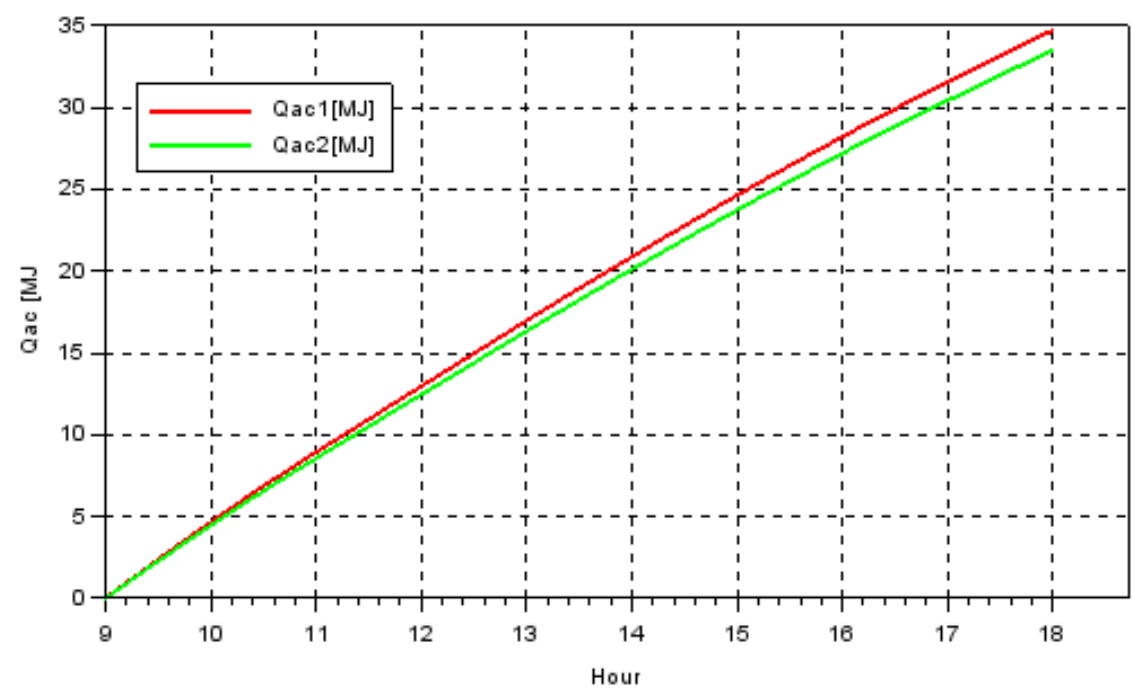

Fig. 14. Time evolution of the amount of heat accumulated in the storage tank over simulation time period for both systems

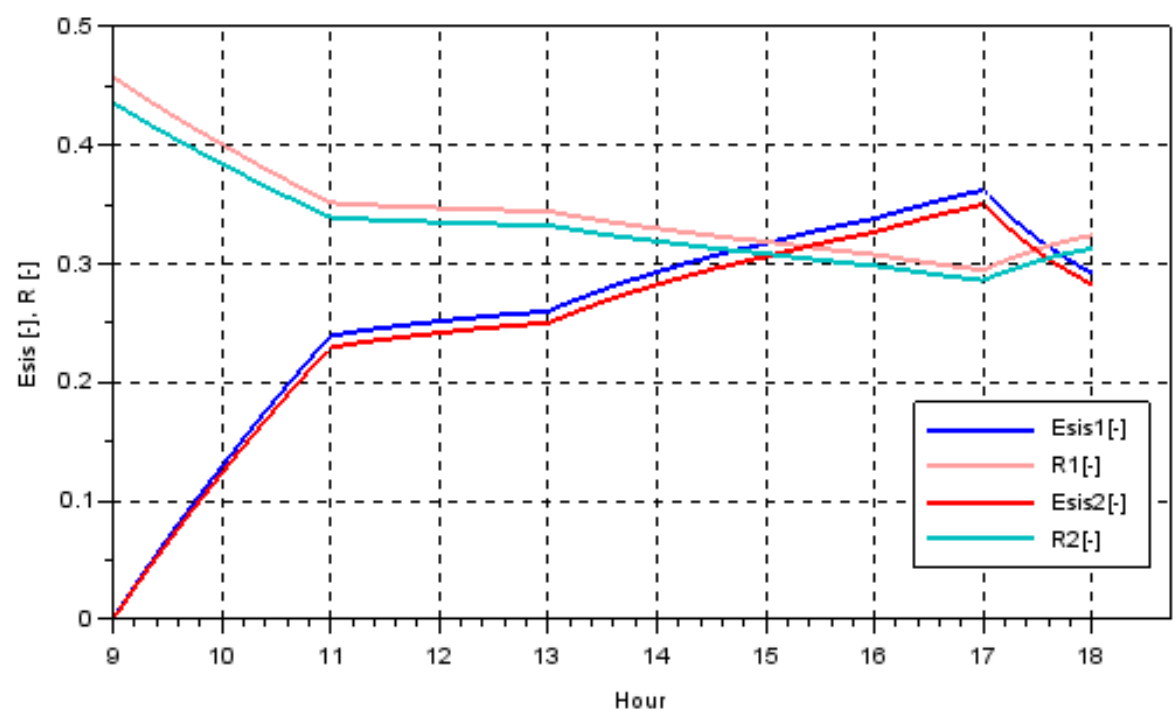

Fig. 15. Time evolution of system efficiency and system performance for both systems

From the comparative analysis of the graphs for the two systems it can be noticed that the system without an inbuilt heat exchanger in the storage tank (index 1) has a slightly better efficiency but is disadvantaged in the situation when it is desired to use as thermal agent a solution other than water (eg. nanofluids) because there is no separation between source agent and domestic hot water (DHW). Also, the system with inbuilt heat exchanger (index 2) has separate the domestic hot water circuit from the thermal agent circuit recirculated by the collectors, thus allowing the thermal agent to be treated for limestone deposits and thus maintain the efficiency of the system. 


\section{CONCLUSION}

The calculation program (Figs. $3 \div 8$ ) elaborated by the author of this article in Scilab-Xcos solves the mathematical equations $(1 \div 19)$ describing the evolution in time of the water temperatures on the flow and return of the heat exchanger primary flow, of the equivalent temperature, the water temperature in the storage tank, the thermal power delivered by the solar system, the amount of heat accumulated in the hot water tank, system efficiency and sperformance of both systems.

By comparative analyses of these mathematical models of the thermal systems, those who want to implement such systems can draw the conclusion which one is appropriate according to the needs of each, considering that each of these systems has advantages and disadvantages.

This program is immediately applicable and is useful in designing, building and operating of heating systems consisting of solar collectors and hot water storage tank and the solar collector coupled with an inbuilt heat exchanger in the storage tank, making simulations and seeing how the parameters mentioned above evolved over the simulation time period and for the specific conditions in each case.

\section{REFERENCES}

[1] S.M. Toropoc, R. Frunzulica, P.D. Toma, Mathematical modeling and simulation of a thermal system using solar radiation as energy source, $8^{\text {th }}$ International Conference on Energy and Environment 2017;

[2] https://www.sistemepanourisolare.ro/dimensionare-panou-solar

[3] F. Iordache, Comportamentul dinamic al echipamentelor şi sistemelor termice, Editura MatrixRom, Bucureşti, 2005;

[4] P.D. Toma, Mathematical modeling and simulation of a thermal system consisting of solar collectors and storage tank with an inbuilt heat exchanger, Scientific Bulletin, Series C, Vol. 80, Iss. 2, U.P.B. 2018;

[5] F. Iordache, Comportamentul dinamic al echipamentelor şi sistemelor termice Culegere de probleme rezolvate, Editura MatrixRom, București, 2003;

[6] http://www.scilab.org.

[7] http://re.jrc.ec.europa.eu/pvgis/apps4/pvest.php?lang=en\&map=europe

[8] F. Iordache, F. Baltaretu., Modelarea si simularea proceselor dinamice de transfer termic, Editura MatrixRom, Bucureşti, 2002;

[9] F. Iordache, F. Baltaretu, B. Caracaleanu, Modelarea si simularea proceselor dinamice de transfer termic - Culegere de probleme, Editura MatrixRom, Bucureşti, 2003;

[10] Ş Vintilă., T. Cruceru, L. Onciu, Instalaţii sanitare şi de gaze, Editura didactică şi pedagogică, R.A. - Bucureşti, 1995;

[11] Ş Vintilă, T. Cruceru, L. Onciu, C. Şerbănescu, Instalaţii sanitare şi de gaze îndrumător de proiectare, Editura tehnică, Bucureşti, 1987;

[12] A. Leca, E.C. Mladin, M. Stan, Transfer de caldură şi masă, Editura tehnică, Bucureşti, 1998.

\section{Note:}

Petric ă Daniel Toma - PhD - S.C. Apa Nova Bucharest S.A., Romania; (e-mail: danielpetre2006@yahoo.com 